\title{
Diatom response to environmental gradients in the high mountain lakes of the Colombia's Eastern Range
}

\author{
Claudia Liliana Muñoz-López ${ }^{1}$ (D) . Carlos A. Rivera-Rondón ${ }^{1}$
}

Received: 8 June 2021 / Accepted: 19 November 2021 / Published online: 29 December 2021

(c) The Author(s) 2021

\begin{abstract}
A survey of 60 high mountain lakes of Colombia's Eastern Range was performed to evaluate the response of surfacesediment diatoms to environmental variables. In each one of these lakes, water samples were taken for physical and chemical characterization, and diatoms were collected from the superficial bottom sediment at the deepest part. Multivariate statistical analyses were made to determine the relationships between environmental and biological data, specifically which environmental variables explain the diatom distribution. For each of these significant environmental variables, optima and ecological tolerances were calculated using the weighted-average method, which allowed for the classification of the species according to their environmental preferences. The lakes showed a wide range of environmental gradients in variables such as $\mathrm{pH}$, alkalinity, and nutrients. In addition, the depth of the lakes was a direct determinant of the light environment of the water column. A total of 339 diatom taxa were identified belonging mainly to the genera Eunotia and Pinnularia. Variables related to $\mathrm{pH}$-alkalinity gradient, trophic condition (nitrates and phosphorus), and physical factors (radiation at the bottom) had a significant effect on diatom composition. Despite the fact that the total organic carbon environmental range was high, the effect of this variable on diatom species composition was not significant. In conclusion, the diatoms of the studied lakes showed a significant ecological relationship with environmental variables which are potentially important in environmental reconstruction. Diatoms in the study sites can provide useful and independent quantitative information to investigate the recent impacts of global change on tropical high mountain ecosystems.
\end{abstract}

Keywords Tropical lakes $\cdot$ Surface sediments $\cdot$ Ecological indicators $\cdot$ Environmental assessment

\section{Introduction}

The variability of diatom species in the mountain lakes of remote areas is mainly attributable to the $\mathrm{pH}$ and alkalinity gradients (Hadley et al. 2013; Köster et al. 2004; RiveraRondón and Catalan 2020; Tolotti 2001). Other variables, such as phosphorus, explain little of the variability of diatom species in mountain regions (Chen et al. 2008; Feret et al. 2017; Hadley et al. 2013). The identification of explanatory variables of diatom distribution requires a regional approach in which the existing potential environmental gradients are included (Juggins and Birks 2012). Diatom ecology of freshwater lakes has been mainly studied in temperate regions

Claudia Liliana Muñoz-López

cl.munoz@javeriana.edu.co

1 Laboratorio de Limnología, UNESIS, Departamento de Biología, Pontificia Universidad Javeriana, Cra. 7 40-62, Bogotá, Colombia
(Curtis et al. 2009; DeNicola et al. 2004; Feret et al. 2017; Rivera-Rondón and Catalan 2020; Schmidt et al. 2004). The Neotropical region is relatively understudied (Benito et al. 2018a) and there are few regional studies on mountain lakes. The different characteristics of these ecosystems require a basic study of diatom ecology because the response could not be comparable to other regions.

Páramo is a high mountain ecosystem located in the Neotropical region at the Andes Range. In Colombia, this ecosystem is located above $3000 \mathrm{~m}$ a.s.l. and it is characterized by high humidity $(>70 \%)$, high daily temperature $\left(\sim 20^{\circ} \mathrm{C}\right)$, radiation oscillation, and mean annual temperatures ranging from 3 to $13{ }^{\circ} \mathrm{C}$ (Buytaert et al. 2006; Castro et al. 2016). The páramo soils are rich in organic matter, mainly due to the large vegetation cover on which, a large number of lakes are located (Buytaert et al. 2006). Accordingly, these lakes are characterized by low mineralized waters, low $\mathrm{pH}$, and high organic carbon (OC) concentration (Zapata et al. 2021). OC plays an important role on organisms, particularly 
in the benthic habitat. However, its effect is an interaction between other lacustrine features such as light penetration, water depth, and lake area (Clarke 2003). Also, hypoxia can be experienced at the bottom of some mountain lakes. Low dissolved oxygen levels facilitate the solubility of phosphorus and can modify the productivity and food web structure (Catalan et al. 2013; Gunkel 2003). Because of their altitudinal location, these lakes are traditionally considered remote ecosystems; that is, they are far from direct human impact (Catalan et al. 2013). However, anthropic activities in the páramo such as agriculture and livestock have increased recently (Mirande and Tracanna 2009) and could have a direct impact on nutrient cycles, productivity, and the trophic status of such lakes. In páramo lakes there are environmental gradients related to notable variability in physical and chemical features, habitat and trophic state conditions, and climate diversity (Donato-Rondón 2001). These factors can influence significantly on the distribution of organisms (Catalan and Donato-Rondón 2016).

Diatoms are considered one of the algal groups with the largest number of species. In addition, they have specialized response to the environment (Benito et al. 2020), which is quantitatively expressed through the ecological optimum and tolerances. The optimum is calculated as the weighted average of the abundance of a species with respect to a variable; the tolerance is calculated as the standard deviation. Using the optima and the abundance of the all species present in a sample, and transfer functions, the values of the variable can be reconstructed. Thus, when a statistical relationship is observed between the diatom community and an environmental variable in a regional context, it can be used successfully for environmental reconstruction (Battarbee 1986; Reavie et al. 2006; Smol 2008; Smol et al. 1998). Variables related to water acidity ( $\mathrm{pH}$, alkalinity, carbon) are reported as the main gradient that influence the diatom composition in high mountain lakes (Hadley et al. 2013; Rivera-Rondón and Catalan 2020; Tolotti 2001). However, it has been found that other variables as phosphorus, depth, and light can also have a significant explanatory value for diatom (Bouchard et al. 2004; Rivera-Rondón and Catalan 2020). The identification of other explanatory variables of diatoms beyond $\mathrm{pH}$ in the páramo lakes, is of great interest since it would allow us to better reconstruct the environmental characteristics of lakes in the past and evaluate the impacts of the climate change.

The aim of this study was to evaluate the effect of water physical and chemical characteristics on the surface-sediment diatoms in high mountain lakes in the Eastern Range of Colombia. A previous study of planktonic diatoms in 23 Colombian mountain lakes, including both sedimentary and volcanic basins, showed that diatom abundance is mainly attributed to conductivity, calcium level, and $\mathrm{pH}$ (Donato Rondón 2001). The lakes that we have studied are located on sedimentary rock composed of rich organic soil, and therefore, we expected acidic conditions, low ionic concentration, and high concentration of organic compounds. Accordingly, we hypothesized that diatom species distribution will be explained mainly by $\mathrm{pH}$ and organic carbon gradients.

\section{Materials and methods}

\section{Study site and sampling design}

This study was based on a survey of 60 high mountain lakes of Colombia's Eastern Range (Fig. 1). This mountain system extends approximately between $1^{\circ} 05^{\prime}$ and $8^{\circ} 40^{\prime} \mathrm{N}$. The lithology consists of sedimentary rocks of continental or transitional marine-continental origin, with some Jurassic plutonic rocks (Gómez et al. 2005). The climate in this range is highly variable with precipitation close to $1500 \mathrm{~mm}$ per year. The rain regime is bimodal, presenting two dry seasons that go from December to March and from June to August (Narváez-Bravo and León-Aristizábal 2001).

To collecting the natural variability of high mountain lakes of Colombia's Eastern Range, an inventory based in maps was carried out (Zapata et al. 2021). Based on this review, ecosystems with extension larger than 0.5 ha and located between 2785 and $3830 \mathrm{~m}$ a.s.l. were selected. The final selection of lakes included factors related to geological, climatic, altitudinal, and protection variability. The final selected lakes are distributed across a broad environmental gradient based on altitudinal range and lake morphology (Table 1; Fig. S1). For each one, a single sampling was carried out during the dry period between February and May 2017, when radiation is the highest, and the effect of dilution by rainfall is reduced.

\section{Physical and chemical characterization}

In each of the lakes and through the use of a handheld sonar, the deepest area was determined, and transparency Secchi was measured. The percentage of radiation at the bottom $\left(\mathrm{I}_{\mathrm{z}}\right)$ was calculated based on the Beer-Lambert law, Secchi disk depth $\left(\mathrm{Z}_{\mathrm{SD}}\right)$, and a light attenuation coefficient of $1.7 / Z_{\mathrm{SD}}$ (Margalef 1983). We use this approximation, since there are no data on the relationship between the light environment in the water column and the Secchi disk. Electrical conductivity, $\mathrm{pH}$, temperature, and dissolved oxygen concentration were measured on the surface using the multiparametric probe YSI 556 (Ruiz 2002; Wetzel and Likens 2000). Additionally, surface water samples were taken to determining alkalinity, calcium $\left(\mathrm{Ca}^{2+}\right)$, sodium $\left(\mathrm{Na}^{+}\right)$, manganese $\left(\mathrm{Mn}^{2+}\right)$, iron $\left(\mathrm{Fe}^{2+}\right)$, magnesium $\left(\mathrm{Mg}^{2+}\right)$, potassium $\left(\mathrm{K}^{+}\right)$, chlorine $\left(\mathrm{Cl}^{-}\right)$, total Kjeldahl nitrogen (TKN), nitrate $\left(\mathrm{NO}_{3}^{-}\right)$, nitrite $\left(\mathrm{NO}_{2}^{-}\right)$, ammonium 
Fig. 1 Geographical location of the lakes studied in the Colombia's Eastern Range

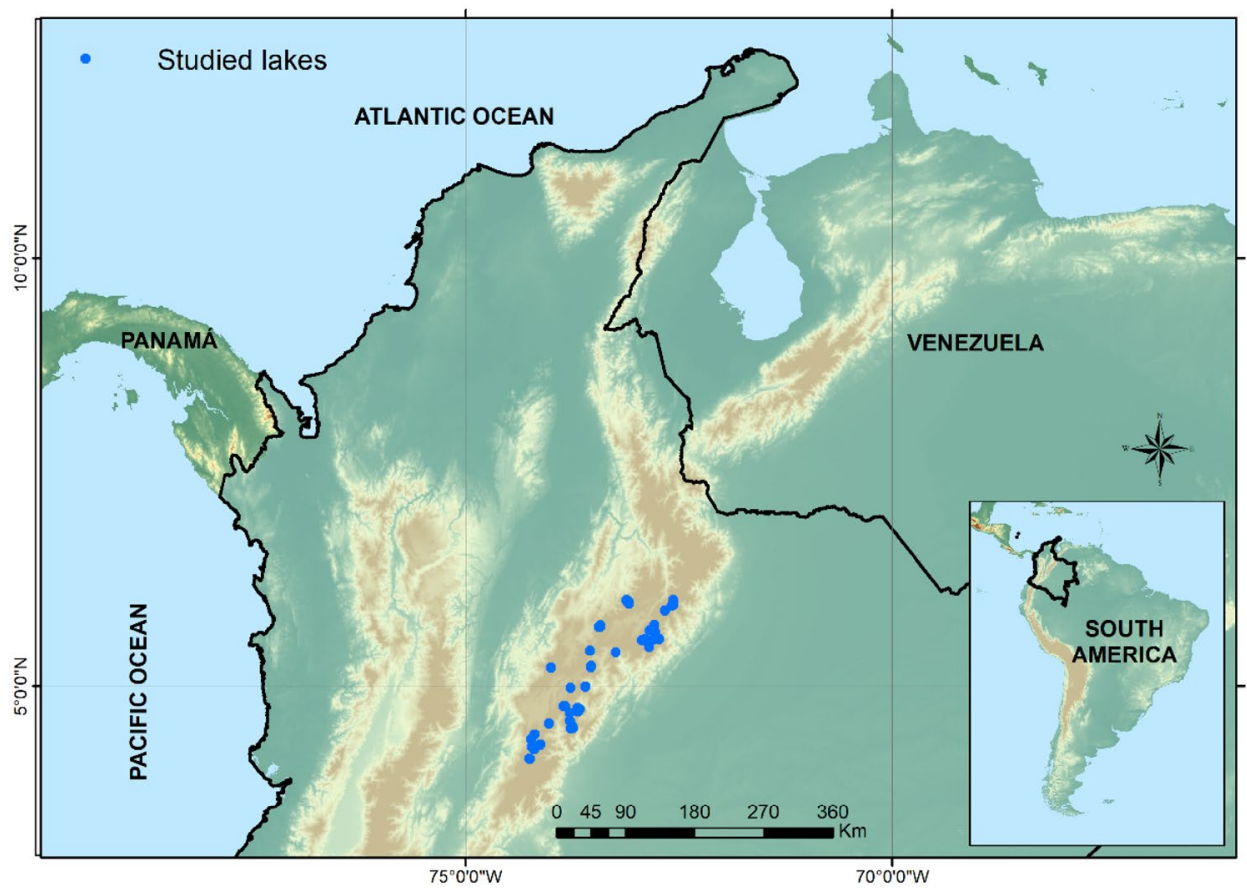

$\left(\mathrm{NH}_{4}^{+}\right)$, total phosphorus (TP), soluble reactive phosphorus (SRP), sulfate $\left(\mathrm{SO}_{4}{ }^{-2}\right)$, total organic carbon (TOC), and silica $\left(\mathrm{SiO}_{2}\right)$ levels, based on the recommendations of APHA et al. (2012). The samples were refrigerated at $4{ }^{\circ} \mathrm{C}$ until chemical analysis (Wetzel and Likens 2000). These analyses were performed at Water Quality Laboratory of the Engineering Faculty of Pontificia Universidad Javeriana-Bogotá.

\section{Diatom collecting and cleaning}

Diatom samples were obtained from the upper $0.5 \mathrm{~cm}$ portion of the sediment, which was collected from the deepest zone of each lake using an Uwitec gravity corer. The samples were digested by an oxidative process that consisted in adding hydrochloric acid $(\mathrm{HCl}, 1 \mathrm{~N})$ and hydrogen peroxide $\left(\mathrm{H}_{2} \mathrm{O}_{2}, 30 \%\right)$. This procedure was carried out in a water bath at $70{ }^{\circ} \mathrm{C}$. The $\mathrm{H}_{2} \mathrm{O}_{2}$ level remained constant throughout the reaction. After digestion, the samples were washed with distilled water and successive centrifugations to eliminate excess reagent. The samples were placed in an ultrasound bath for 5 minutes to disperse the valves. The diatom suspension was diluted in distilled water and placed on a round coverslip. They were allowed to dry at room temperature in a place protected from vibrations for 24 to $48 \mathrm{~h}$. The samples were mounted on permanent slides using the synthetic mounting medium Naphrax (Battarbee 1986; Nagy 2011).

\section{Diatom taxonomic identification and counting}

The diatoms were observed under a Zeiss Axio Imager A2 inferential contrast microscope at a magnification of 1000x. A minimum of 1000 valves per sample were counted (Alvial et al. 2008). Regional and general iconographic books were used diatom identification such as Metzeltin and Lange-Bertalot (1998), Metzeltin and Lange-Bertalot (2007), Rumrich et al. (2000), and Hofmann et al. (2011). A taxonomic identity was assigned to the minimum possible resolution. However, due to very few regional taxonomic studies, a large number of species were not identified. Therefore, the specimens similar to a known species but without full identification were labeled as "cf." and those showing differences in diagnostic traits were labeled "aff." (Rivera-Rondón and Catalan 2017). Photographs of some important species that could not be identified (referred as $s p$. and aff.) are included in the supplemental material (Fig. S4).

\section{Numerical analysis}

First, lakes were ordinated on the basis of diatom species through nonmetric multidimensional scaling with Bray-Curtis distance. Second, the relationship between diatoms and environmental variables was studied through a direct gradient analysis approach (Ter Braak 1986). This technique maximizes the main sources of variation that separate the niches of the species (Ter Braak and Verdonschot 1995). Redundancy Analysis (RDA) was performed using the Hellinger transformation for species data (Legendre and Gallagher 
Table 1 Summary of morphometric, physical, and chemical characteristics of the studied lakes

\begin{tabular}{|c|c|c|c|c|c|c|}
\hline Variable & Minimum & Q1 & Median & Mean & Q3 & Maximum \\
\hline \multicolumn{7}{|l|}{ Morphometric variables } \\
\hline Lake area (ha) & 0.2 & 1.37 & 2.67 & 190.6 & 6.7 & 5532.7 \\
\hline Maximum depth (m) & 0.35 & 3.78 & 6.65 & 11.14 & 11.9 & 65.5 \\
\hline Altitude (m a.s.l) & 2785 & 3418 & 3582 & 3485 & 3668 & 3830 \\
\hline \multicolumn{7}{|l|}{ Habitat variable } \\
\hline Irradiance at the bottom (\%) & 0.000 & 0.19 & 2.88 & 6.56 & 11.25 & 65.9 \\
\hline \multicolumn{7}{|l|}{ Physical variables } \\
\hline $\mathrm{pH}$ & 4.68 & 5.3 & 6.27 & 6.25 & 6.92 & 8.5 \\
\hline Temperature $\left({ }^{\circ} \mathrm{C}\right)$ & 9.4 & 11.38 & 16.65 & 12.9 & 14.1 & 18.8 \\
\hline Conductivity $\left(\mu \mathrm{S} \mathrm{cm}^{-1}\right)$ & 2 & 4 & 6 & 14.01 & 12.25 & 97 \\
\hline Transparency (m) & 0.3 & 1.5 & 3.2 & 3.4 & 5.05 & 8.4 \\
\hline Dissolved oxygen $\left(\mathrm{mg} \mathrm{L}^{-1}\right)$ & 4.75 & 6.3 & 6.82 & 6.73 & 7.2 & 8.2 \\
\hline \multicolumn{7}{|l|}{ Chemical variables } \\
\hline Alkalinity $\left(\mathrm{mg} \mathrm{CaCO}_{3} \mathrm{~L}^{-1}\right)$ & 0.25 & 1.37 & 1.99 & 6.05 & 7.97 & 44.85 \\
\hline Total Organic Carbon $\left(\mathrm{mg} \mathrm{L}^{-1}\right)$ & 2.57 & 4.54 & 6.03 & 6.39 & 7.27 & 16.19 \\
\hline Total Phosphorus (mg L ${ }^{-1}$ ) & 0.019 & 0.28 & 0.36 & 0.53 & 0.62 & 2.04 \\
\hline Total Kjeldahl Nitrogen $\left(\mathrm{mg} \mathrm{L}^{-1}\right)$ & 0.7 & 0.84 & 0.98 & 1.03 & 1.12 & 1.54 \\
\hline Ammonium $\left(\mathrm{mg} \mathrm{L}^{-1}\right)$ & 0.28 & 0.42 & 0.42 & 0.52 & 0.7 & 0.98 \\
\hline Nitrate $\left(\mathrm{mg} \mathrm{L}^{-1}\right)$ & 0.0005 & 0.001 & 0.008 & 0.02 & 0.015 & 0.18 \\
\hline Nitrite $\left(\mathrm{mg} \mathrm{L}^{-1}\right)$ & 0.0005 & 0.0005 & 0.0017 & 0.003 & 0.005 & 0.026 \\
\hline Chlorine $\left(\mathrm{mg} \mathrm{L}^{-1}\right)$ & 0.025 & 0.0025 & 0.19 & 0.47 & 0.36 & 4.1 \\
\hline Sulfate $\left(\mathrm{mg} \mathrm{L}^{-1}\right)$ & 0.025 & 0.0025 & 0.25 & 1.28 & 0.75 & 44.06 \\
\hline Sodium $\left(\mathrm{mg} \mathrm{L}^{-1}\right)$ & 0.37 & 0.58 & 0.67 & 0.77 & 0.92 & 2.51 \\
\hline Manganese $\left(\mathrm{mg} \mathrm{L}^{-1}\right)$ & 0.003 & 0.008 & 0.013 & 0.02 & 0.02 & 0.087 \\
\hline Magnesium $\left(\mathrm{mg} \mathrm{L}^{-1}\right)$ & 0.04 & 0.09 & 0.16 & 0.33 & 0.36 & 1.65 \\
\hline Potassium $\left(\mathrm{mg} \mathrm{L}^{-1}\right)$ & 0.03 & 0.08 & 0.12 & 0.2 & 0.2 & 1.94 \\
\hline Iron $\left(\mathrm{mg} \mathrm{L}^{-1}\right)$ & 0.03 & 0.14 & 0.23 & 0.34 & 0.45 & 2.2 \\
\hline Calcium $\left(\mathrm{mg} \mathrm{L}^{-1}\right)$ & 0.17 & 0.33 & 0.72 & 1.57 & 1.67 & 8.81 \\
\hline Silica $\left(\mathrm{mg} \mathrm{L}^{-1}\right)$ & 0.13 & 0.76 & 1.23 & 1.43 & 1.82 & 4.63 \\
\hline
\end{tabular}

Q1 and Q3 are quartiles 1 and 3, respectively
2001). The environmental variables were transformed using the $\log x+1$ function (García-Berthou et al. 2009; McCune and Grace 2002). Dissolved oxygen level, $\mathrm{pH}$, and temperature were not transformed because they already had a central distribution. Initially, the analysis included diatom species that were found in more than three lakes $(n=190)$ and considering environmental variables with a variance inflation factor $>5$. Forward selection method was applied to choose the variables that significantly explained diatom variance.

Then, a second analysis was performed using the significant variables. The statistical significance of the RDA model was calculated using the Monte Carlo test with 999 permutations (Lepš and Šmilauer 2003). To identify the groups of species exhibiting potential for environmental reconstruction, RDA was performed using each significant variable as explanatory and the other significant variables as covariables. These analyses were carried out using CANOCO v. 4.5 software.
The optima for species that explained above 5\% of each RDA were analyzed respect to lakes classification. The species optima and tolerances were calculated using weighted average with standard deviation (Oksanen et al. 1988). This procedure was performed using $\mathrm{R}$ language packages: vegan (Oksanen et al. 2020) and rioja (Juggins 2020). Lakes were classified by means the variables with potential use in environmental reconstruction $\left(\mathrm{pH}, \mathrm{I}_{\mathrm{z}}, \mathrm{TP}\right.$, and $\left.\mathrm{NO}_{3}{ }^{-}\right)$, and according to ecological thresholds affecting diatom distribution in freshwater ecosystems, thus:

The lakes were classified based on the species preferences. For $\mathrm{pH}$, two groups were established: 1. $<6.5$ and 2. $>6.5$, which corresponds to acidophilic and circumneutral-alkalophilic. For $\mathrm{I}_{\mathrm{Z}}$, lakes were grouped in three classes: 1. $<1 \%$ (limited by light), 2.1 to $9 \%$ (moderate radiation), and 3. $>10 \%$ (high radiation), according to the limit conditions for algal photosynthesis (Rivera-Rondón and Catalan 2020). 
The lakes had high phosphorus and nitrogen concentrations, and therefore, we classified them in groups exhibiting mesotrophic and eutrophic conditions. Thus, for TP, the lakes were classified into the two groups: 1. $<0.3$ and 2. $>0.3 \mathrm{mg} \mathrm{L}^{-1}$, and for $\mathrm{NO}_{3}^{-}: \mathbf{1}$. $<0.1$ and 2. $>0.1 \mathrm{mg} \mathrm{L}^{-1}$. According to data distribution and Wetzel (2000), these groups for both variables correspond to mesotrophic and eutrophic lakes, respectively.

\section{Results}

\section{General description of the physical and chemical characteristics of the lakes}

The lakes exhibited varied conditions in terms of their physical and chemical characteristics, especially in $\mathrm{pH}$, alkalinity, and nutrients. The $\mathrm{pH}$ ranged between 4.7 and 8.5; most of the lakes were acidic (33), 27 of them had a circumneutralalkalophilic $\mathrm{pH}$ values. In addition, lake waters were characterized by their low ionic content reflected by low alkalinity. With regard to nutrients, TP level ranged between 0.019 and $2.04 \mathrm{mg} \mathrm{L}^{-1}$. In general, the lakes presented meso-eutrophic condition, with phosphorus concentrations of $>0.3 \mathrm{mg} \mathrm{L}^{-1}$ and, nitrate concentration $>0.01 \mathrm{mg} \mathrm{L}^{-1}$. $\mathrm{SiO}_{2}$ levels were between 0.13 and $4.63 \mathrm{mg} \mathrm{L}^{-1}$, grouping a high number of systems around the average (Fig. S2).

Most of the lakes studied were not more than 10-m deep and presented transparency values that ranged between 4 and $8 \mathrm{~m}$. Thus, a large number of systems were well lit at the bottom, which allows the development of macrophytes and algal biofilms. The percentage of radiation at the bottom allowed to establish that 25 lakes were limited by light, 16 had a moderate radiation, and 19 presented high radiation (Fig. S3).

\section{Diatom assemblages}

A total of 339 species that belong to 58 genera of diatoms were identified. The morphological group with the highest number of species was the symmetric biraphid (110 species) followed by eunotioid (91), asymmetric biraphid (50), and araphid (33); epithemioid and surirelloid had lower number of species (Fig. 2A).

The genera with a higher number of species were Eunotia (88), Pinnularia (32), Gomphonema (18), Fragilaria (14), Nitzschia (14), Encyonema (12), Encyonopsis (12), and Navicula (10) (Fig. 2B). The genera with less than 3 species were Achnanthes, Brachysira, Chamaepinnularia, Luticola, Neidium, Nupela, Sellaphora, Stauroneis, Staurosira and Tabellaria. Encyonema was the most frequent genus found in the 60 sampled lakes, followed by Eunotia, Frustulia, Pinnularia, and Brachysira, which were found in most of the systems $(58,57,56$, and 55 , respectively).

The most frequent species were Brachysira brebissonii R.Ross, Frustulia magaliesmontana Cholnoky, Asterionella formosa Hassall, Actinella punctata F.W.Lewis, Eunotia aff. incisadistans Lange-Bertalot \& Sienkiewicz (Fig. S4-G), Aulacoseira cf. lirata (Ehrenberg) R. Ross, Semiorbis hemicyclus (Ehrenberg) R.M. Patrick, Staurosira venter (Ehrenberg) Cleve \& J. D. Möller, Eunotia cf. acutinasuta Metzeltin \& Lange-Bertalot, and Achnanthidium minutissimum (Kützing) Czarnecki.

According to NMDS, diatoms assemblages of acid lakes were distinct from those of circumneutral-alkalophilic lakes (Fig. 3A). For light, phosphorus, and, nitrate the same pattern was found (Fig. 3B-D), and made it possible
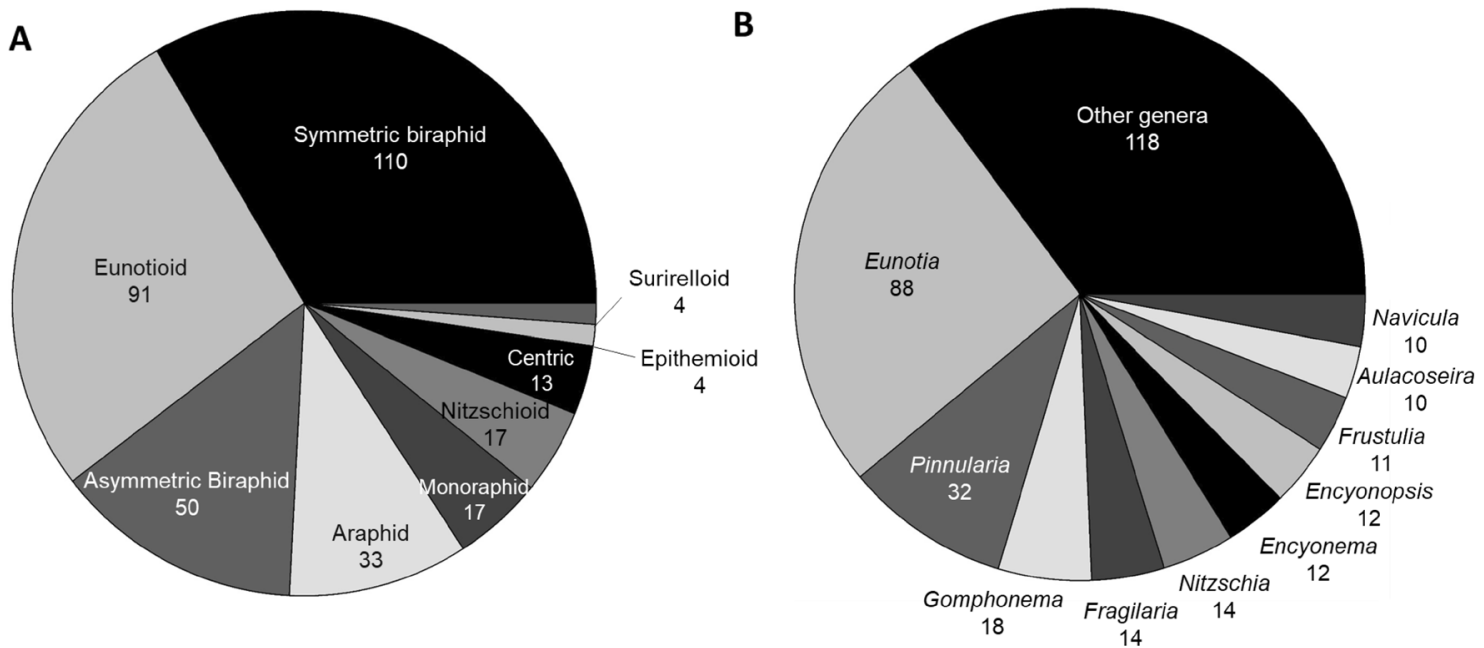

Fig. 2 Number of species by morphological group (A) and percentage of species contribution per genera (B) 

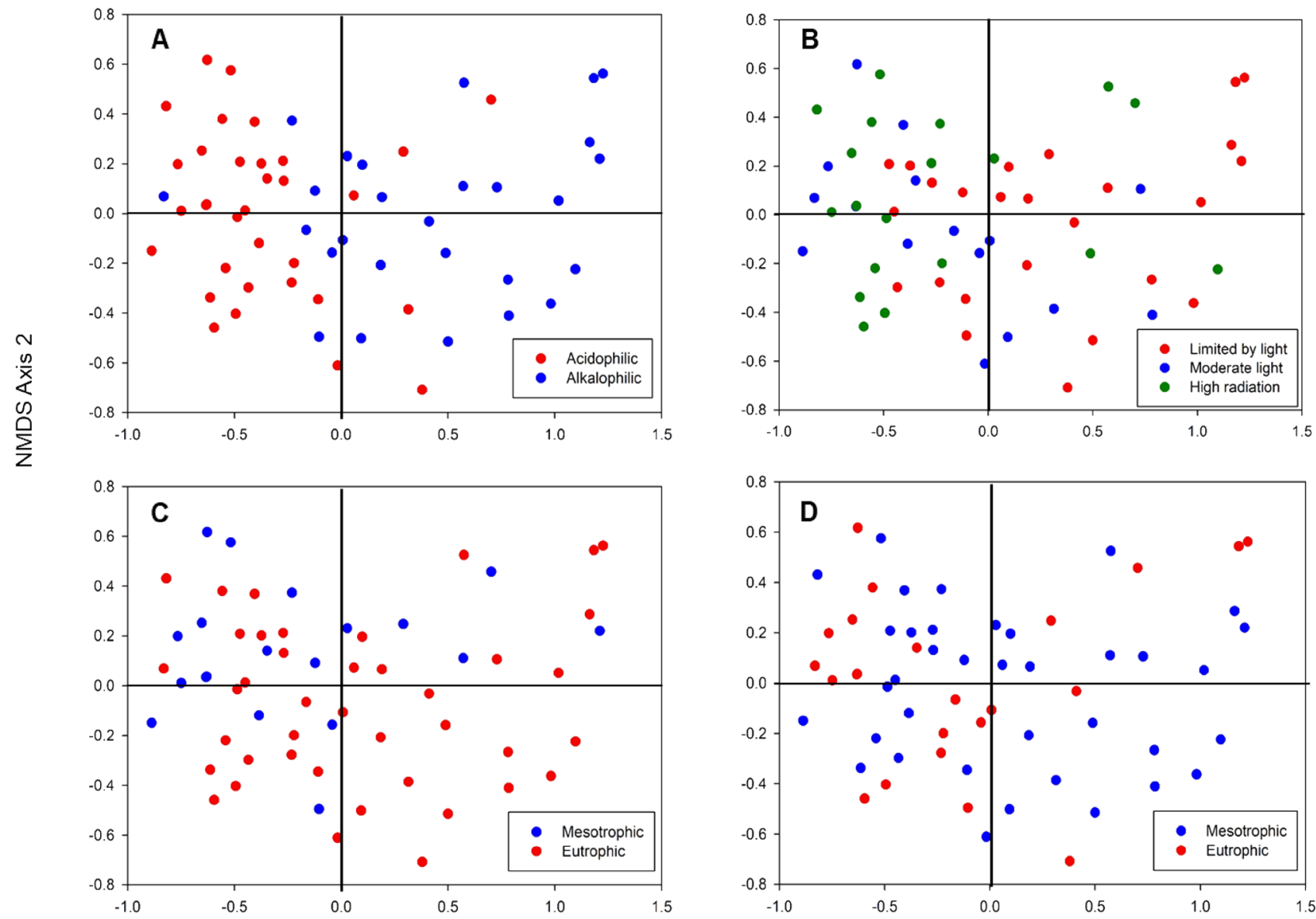

NMDS Axis 1

Fig. 3 Nonmetric multidimensional scaling (NMDS) ordinations of samples based on diatoms (190 taxa). Samples are grouped according to $\mathbf{A ~ p H}$ (acidophilic: $<6.5$, circumneutral-alkalophilic: $>6.5$ ), B percentage of radiation at the bottom: $\mathrm{I}_{\mathrm{z}}$ (limited by light: $<1 \%$, mod-

to distinguishing many of mesotrophic and eutrophic lakes according to nutrient concentration.

\section{Species-environment relationships}

RDA explained $18.4 \%$ of the variance of the data of the species in the first two axes: $13.2 \%$ and $5.2 \%$, respectively (Fig. 4, Tables 2 and 3). Six parameters explained the variance of the diatoms significantly. Axis 1 was mainly explained by $\mathrm{pH}(r=0.77)$, alkalinity $(r=0.73)$, and $\mathrm{SiO}_{2}$ level $(r=0.45)$. Axis 2 was associated with TP $(r=0.29)$. $\mathrm{I}_{\mathrm{z}}$ was correlated with both the axes $(r=-0.46$ and $r=-0.43$, respectively). $\mathrm{NO}_{3}{ }^{-}$level showed low correlation with the first two axes.

RDA showed that the relative abundance of Cocconeis euglypta Ehrenberg, Staurosira binodis (Ehrenberg) Lange-Bertalot, Sellaphora capitata D. G. Mann \& S. erate radiation: $1-9 \%$, and high radiation: $>10 \%), \mathbf{C}$ total phosphorus (mesotrophic: $<0.3$, and eutrophic $>0.3 \mathrm{mg} \mathrm{L}^{-1}$ ), and $\mathbf{D}$ nitrate (mesotrophic: $<0.1$, and eutrophic $>0.1 \mathrm{mg} \mathrm{L}^{-1}$ )

M. McDonald, and Gomphonema pumilum var. rigidum E.Reichardt \& Lange-Bertalot was associated with high $\mathrm{pH}$ values. In contrast, $F$. magaliesmontana, A. punctata, Eunotia mucophila Lange-Bertalot, Nörpel-Schempp \& Alles, and Eunotia cf. incisatula Metzeltin \& Lange-Bertalot were associated with low $\mathrm{pH}$. It was further observed that Reimeria sinuata (W. Gregory) Kociolek \& Stoermer, Staurosirella pinnata (Ehrenberg) D.M. Williams \& Round, A. minutissimum, and $S$. venter were associated with high alkalinity. For 19 taxa, pH explained the highest amount of variation (Fig. 5, Table S1). Acidophilic species were found, such as A. punctata and Encyonopsis sp. No. 1 Ojo de Agua (Fig S3). Some species distributed in the circumneutral-alkalophilic $\mathrm{pH}$ range were Tabellaria fenestrata (Lyngbye) Kützing Encyonema neogracile Krammer, $S$. pinnata, Sellaphora pseudoventralis (Hustedt) Chudaev \& Gololobova, Discostella stelligera (Cleve \& Grunow) Houk 

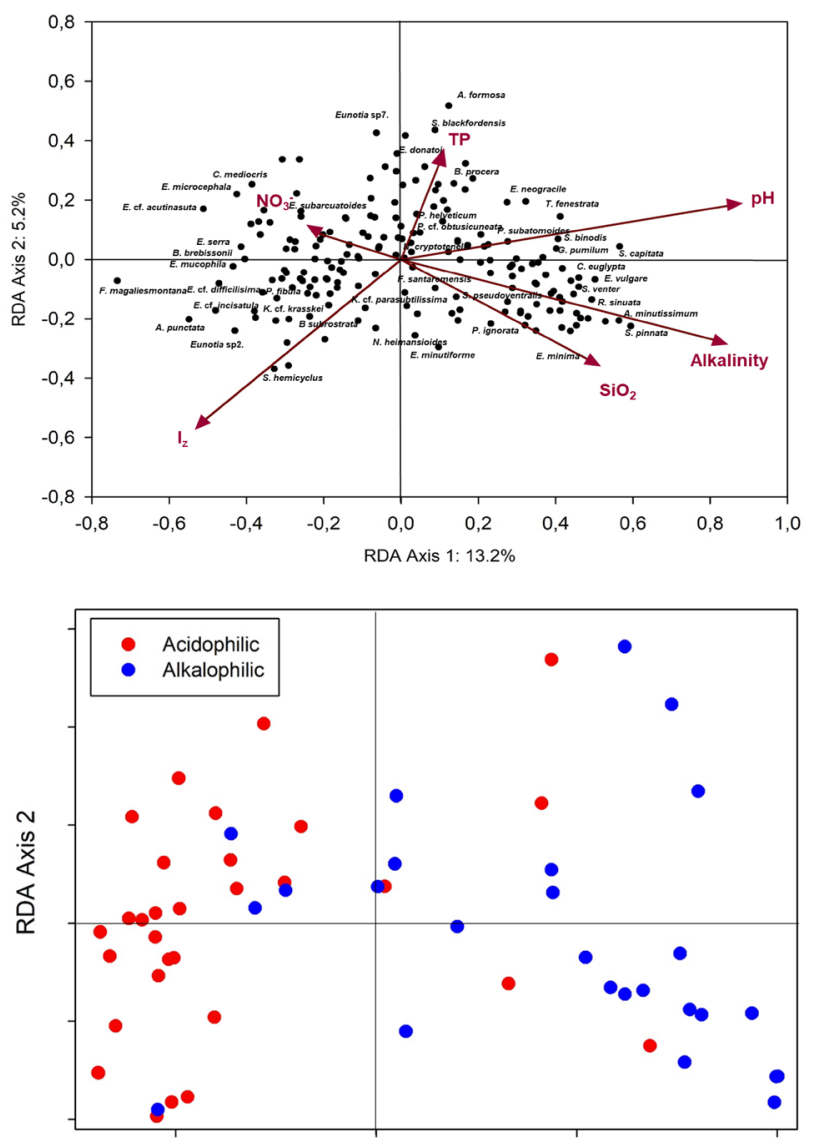

RDA Axis 1

Fig. 4 Biplot based on the canonical redundancy analysis. (Top) Relationship between the diatoms of the surface sediments and the significant environmental variables $(n=60$, taxa $=190)$. (Bottom) Lake distribution based on $\mathrm{pH}$ groups. $I_{z}$ percentage of radiation at the bottom, $\mathrm{TP}$ Total phosphorus, $\mathrm{NO}_{3}^{-}$: nitrate, $\mathrm{SiO}_{2}$ silica. (Names of more frequent taxa are included)

\& Klee, Hannaea arcus (Ehrenberg) Patrick, among others. Encyonema cf. subjavanicum Krammer and A. formosa showed high tolerance to changes in $\mathrm{pH}$.

S. hemicyclus and Encyonopsis sp. No. 1 Ojo de Agua (Fig S3) showed a relationship with high percentages of radiation at the bottom $\left(\mathrm{I}_{\mathrm{z}}\right)$. In contrast, Asterionella formosa Hassall was associated with low $\mathrm{I}_{\mathrm{Z}}$. Diatom species showed high tolerance to $I_{Z}$ (Fig. 5). Some taxa with an optimum below $1 \%$ of radiation were Stauroforma exiguiformis (Lange-Bertalot) R.J.Flower, V.J.Jones \& Round, Cavinula cocconeiformis (W.Gregory ex Greville) D. G. Mann \& A. J. Stickle, and Nitzschia paleaeformis Hustedt. Some species with optimum between 1 and $9 \%$ were Eunotia parasiolii Metzeltin \& Lange-Bertalot, Placoneis ignorata (Schimanski) Lange-Bertalot, Neidium cf. krasskei Metzeltin \& Lange-Bertalot, and Eolimna minima (Grunow) Lange-Bertalot sensu lato. Finally, diatom species with optimum above $10 \%$ were Aulacoseira cf. alpigena
Table 2 Diatom variance explained by environmental variables according to Forward Selection method

\begin{tabular}{llll}
\hline Variable & $\lambda$ & $p$ & $F$ \\
\hline $\mathrm{pH}$ & 0.11 & 0.001 & 6.84 \\
Alkalinity & 0.04 & 0.001 & 2.87 \\
Silica $\left(\mathrm{SiO}_{2}\right)$ & 0.03 & 0.001 & 2.49 \\
Irradiance at the bottom $\left(\mathrm{I}_{\mathrm{z}}\right)$ & 0.04 & 0.001 & 2.14 \\
Total Phosphorus & 0.03 & 0.002 & 1.88 \\
Nitrate $\left(\mathrm{NO}_{3}{ }^{-}\right)$ & 0.03 & 0.006 & 1.74 \\
Sodium $\left(\mathrm{Na}^{+}\right)$ & 0.02 & 0.035 & 1.54 \\
Total $\mathrm{Kjedahl} \mathrm{Nitrogen}_{\text {Manganese }\left(\mathrm{Mn}^{2+}\right)}$ & 0.02 & 0.061 & 1.41 \\
Calcium $\left(\mathrm{Ca}^{2+}\right)$ & 0.01 & 0.066 & 1.41 \\
Sulfate $\left(\mathrm{SO}_{4}{ }^{2-}\right)$ & 0.02 & 0.240 & 1.14 \\
Total Organic Carbon & 0.01 & 0.418 & 1.05 \\
Iron $\left(\mathrm{Fe}^{2+}\right)$ & 0.02 & 0.375 & 1.04 \\
Magnesium $\left(\mathrm{Mg}^{2+}\right)$ & 0.01 & 0.712 & 0.85 \\
\hline
\end{tabular}

$\lambda$ fraction of the variance explained, $p$ p value, $F$ significance test

(Grunow) Krammer, Kobayasiella cf. krasskei (Metzeltin \& Lange-Bertalot) Lange-Bertalot, and Pinnularia tenuistriata var. rostrata Hustedt. On the other hand, Eunotia meisteri Hustedt and Fragilaria santaremensis Metzeltin \& LangeBertalot were the most tolerant to variation of radiation at the bottom (Table S2).

The taxa related to high phosphorus concentration according to RDA were Psammothidium helveticum (Hustedt) Bukhtiyarova \& Round, Pinnularia cf. obtusicuneata Lange-Bertalot, and Navicula cryptotenella Lange-Bertalot. For this variable, 16 taxa were explained significantly, and only 18 species had optimum above $0.3 \mathrm{mg} \mathrm{L}^{-1}$. Some potential indicator species of low trophy were Peronia fibula (Brébisson ex Kützing) R.Ross, Pinnularia cf. microstauron (Ehrenberg) Cleve, and some representatives of the genus Eunotia (E. donatoi and E. cf. incisatula; Fig. 5, Table S3). On the other hand, Gomphonema acuminatum Ehrenberg 1832, Nitzschia cf. lacuum Lange-Bertalot, and Navicula cryptocephala Kützing were an indicator of high TP values.

Surirella robusta Ehrenberg and Chamaepinnularia mediocris (Krasske) Lange-Bertalot were associated with high nitrate concentrations. Thus, for 18 taxa, $\mathrm{NO}_{3}{ }^{-}$explained the highest amount of variation. Species such as Encyonopsis recta Krammer, Kobayasiella cf. parasubtilissima (H.Kobayasi and Nagumo) LangeBertalot, Encyonema minutiforme Krammer, Frustulia cf. altimontana Metzeltin \& Lange-Bertalot, and Eunotia sp. No. 2 Guacheneque (Fig S3-C) showed a higher significant relationship and were related with a high concentration of $\mathrm{NO}_{3}{ }^{-}$(Fig. 5). Thirty-seven taxa presented optimum $<0.01 \mathrm{mg} \mathrm{L}^{-1}$ and the remaining $>0.01 \mathrm{mg} \mathrm{L}^{-1}$. Epithemia turgida (Ehrenberg) and S. robusta presented 
Table 3 Summary of the Canonical Redundancy Analysis for significant environmental variables and diatoms found in surface sediments (Monte-Carlo test: $p<0.05)$
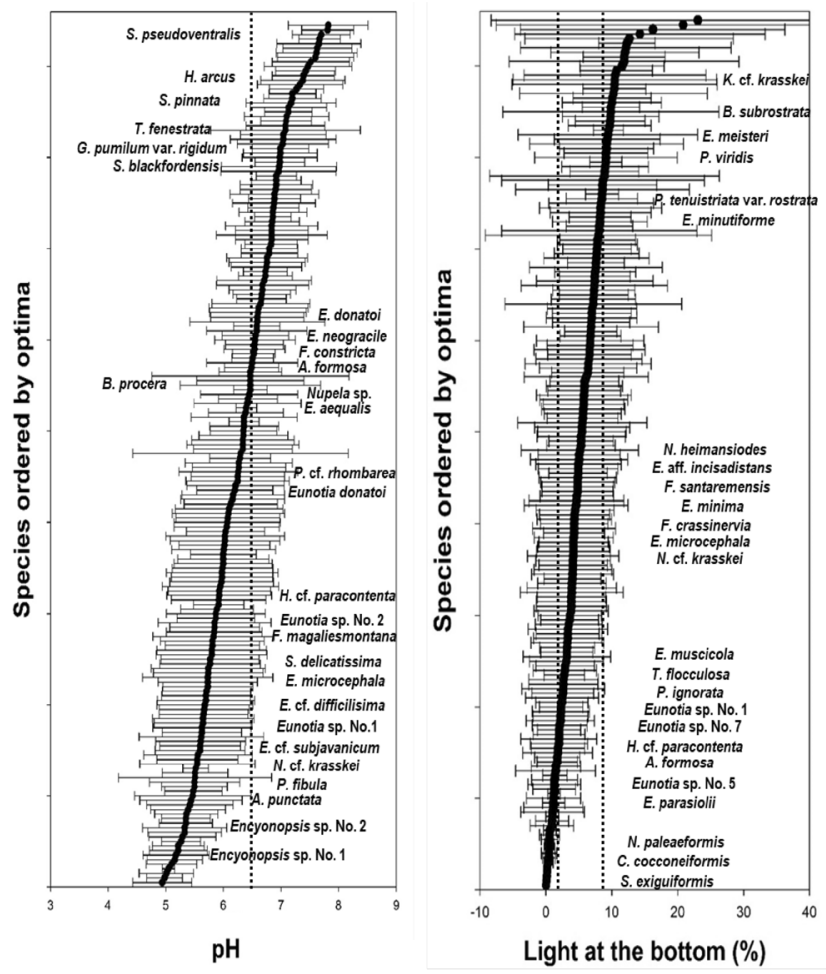

Fig. 5 Optima and diatom distribution ranges for $\mathrm{pH}$, percentage of radiation at the bottom: $I_{z}$, total phosphorus and nitrate; Taxa $=190$. The groups are indicated by the dotted line, $\mathrm{pH}: \mathbf{1} .<6.5,2 .>6.5$ corresponding to acidophilic and circumneutral-alkalophilic; $\mathrm{I}_{\mathrm{z}}: \mathbf{1 .}<1 \%$

the highest optimum. N. cryptotenella, and Brachysira procera Lange-Bertalot \& Gerd Moser showed high tolerance to changes in this variable. S. venter, S. pinnata, and Fragilariforma constricta (Ehrenberg) D. M. Williams \& Round belonged to the group of diatoms in lakes of low $\mathrm{NO}_{3}{ }^{-}$concentration (Table S4).

A second graph is presented to show the distribution of lakes in groups (Fig. 4). It is observed that there are two types of lakes distinguished by the $\mathrm{pH}$ values: acidophilic and circumneutral-alkalophilic, and their assemblages.
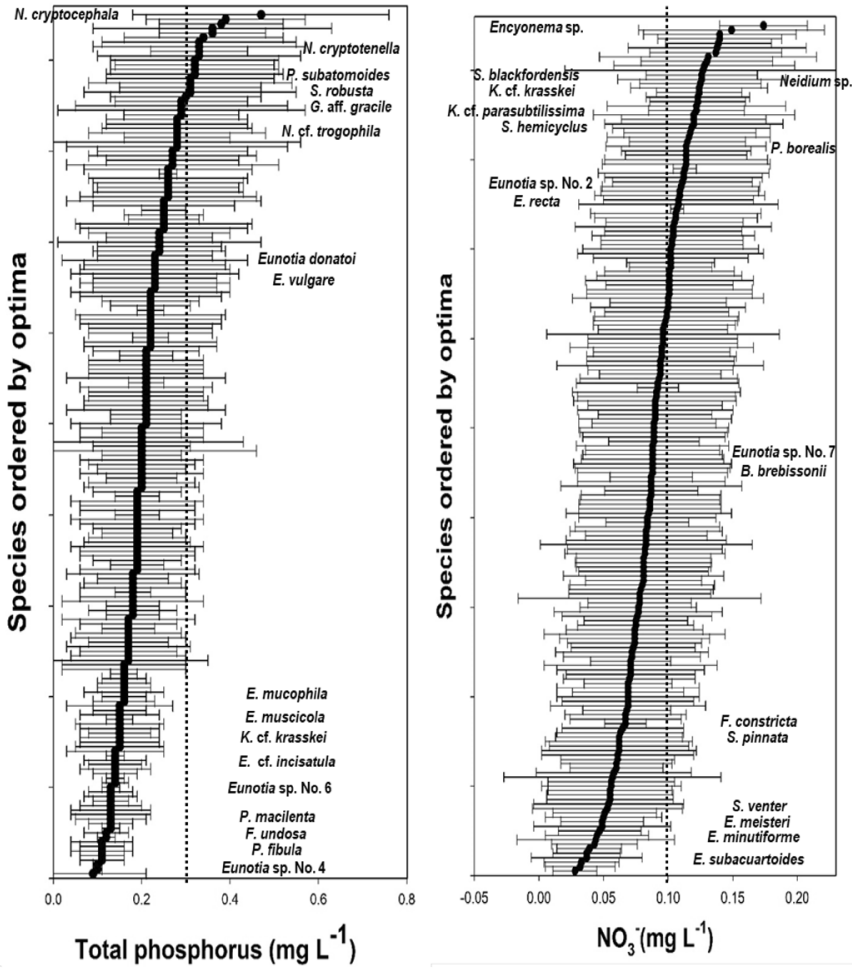

(limited by light), 2. between 1 and $9 \%$ (moderate radiation) and 3. $>10 \%$ (high radiation); TP: 1. $<0.3$ (mesotrophic) and $2 .>0.3 \mathrm{mg}$ $\mathrm{L}^{-1}$ (eutrophic); for $\mathrm{NO}_{3}^{-}: \mathbf{1} .<0.1$ (mesotrophic) and 2. $>0.1 \mathrm{mg} \mathrm{L}$ (eutrophic). (Names of more related taxa are included)

\section{Discussion}

\section{Diatom composition in the context of mountain and remote lakes}

A total of 339 diatom taxa were recorder on the surface sediments. In the context of high-altitude lakes, this value is lower than that reported by Hadley et al. (2013) in High Arctic Canada lakes, and in the Pyrenees (Rivera-Rondón 
and Catalan 2017), but is close to one reported by Rosén et al. (2000) and Feret et al. (2017) in Sweden boreal and French Alps systems, respectively. However, some specimens were not identified to the species level or do not correspond to the morphology reported in the Andean and South American ecosystems (Metzeltin and LangeBertalot 1998, 2007; Rumrich et al. 2000), which means that there is a great taxonomic challenge and the species richness could increase.

Regional studies of diatom composition in Neotropical regions have focused on the lowland freshwater ecosystems (Costa et al. 2017; Sala et al. 2002; Wetzel 2011) or Andean rivers (Díaz-Quirós and Rivera-Rondón 2004; Pedraza- Garzón and Donato-Rondón 2011). Therefore, this work is an approximation to the diatomological knowledge of lentic systems located in the Colombia high mountains.

Considering morphological groups, the highest number of species corresponded to symmetric biraphid and eunotioid. This contrasts with what has been found in other mountain lakes, where the greatest specific richness has been associated with the Naviculoid and Monaraphid groups (RiveraRondón and Catalan 2017). However, these groups are artificial and not strictly evolutionary and the purpose of their use is to facilitate the diatoms identification by morphological similarities (Spaulding et al. 2021).

The genera Eunotia and Pinnularia were the ones with a higher number of species in this study. Eunotia was also frequent. This result corresponds with a meta-analysis performed in several aquatic systems of South America (Benito et al. 2018b). Eunotia is strongly favored by aciditic conditions (Sala et al. 2002) and Pinnularia by their movement capacity on the sediment surface (Linares Cuesta et al. 2007). Frustulia and Actinella were also some frequent genera in these lakes due to their affinity to highly acidic environments (Pan and Stevenson 1996; Rivera-Rondón and Catalan 2017; Round et al. 1990; Siver and Baskette 2004).

Eunotia and Actinella have also been found in waters with a high content of humic substances and low conductivity (Lange-Bertalot et al. 2011; Sioli 1984). Despite their higher species richness and prevalence in these lakes, few taxonomic studies have been performed based on these genera in the tropical Andes. A more detail study of their taxonomy and ecology could help in the development of indicator systems in acidic environments such as the páramo lakes. In contrast, for more alkaline values, Staurosirella was found due their alkalophilic preferences (Jacques et al. 2016; Paull et al. 2008). Encyonema was the most frequent genus, since it was found in the 60 lakes studied. According to Krammer (1997), this taxon is common in systems with low ionic contents, such as those evaluated in this work. In addition, Encyonema spp. are one the most frequent in the mountain lakes floras (Feret et al. 2017).
The sediment surface diatom flora of high-altitude lakes makes up by benthic and planktonic taxa, being $A$. minutissimum, S. venter, Aulacoseria spp., D. stelligera, and Eunotia spp. the most representative ones. These taxa are indicative of a wide range of environmental conditions, related to $\mathrm{pH}$ and nutrients (Benito et al. 2020). This is consistent with the most frequent species reported in this study.

F. magaliesmontana has been characterized as a dominant species in lakes with $\mathrm{pH}$ values below 5 (Donato-Rondón 2001; Thomas and John 2010). Also, it is considered a cosmopolitan species, with a wide ecological niche (Beier and Lange-Bertalot 2007; Kilroy et al. 2007); aspects that make it useful for biomonitoring $\mathrm{pH}$ in remote areas (Kilroy et al. 2006). It could be a tool for developing indicators for studied lakes, due this species was the most frequent.

A. punctata is a taxon widespread in South America (Metzeltin and Lange-Bertalot 2007), and it is related to highly acidic waters with humic substances and oligotrophic conditions (Melo et al. 2010; Round et al. 1990). Although there are records of this species in some Colombian páramo lakes (Sierra-Arango et al. 2014), ecological traits of this species only have been studied in Amazon region (Canani et al. 2018). In other high mountain lakes, some species of Actinella, between these A. punctata are used to evaluate the possible paleoclimate change effect during the middle Eocene, on heteropolar eunotioid diatoms diversification and biogeography; specially the adaptation for attachment as survival mechanism and a tool to reconstructing the lakes ontogeny (Siver et al. 2015).

E. mucophila and E. cf. incisatula have been reported as species frequently associated with acidic waters, too. $E$. mucophila become abundant in $\mathrm{pH}$ values between 5 and 6 (Clarke 2003; Glushchenkoa and Kulikovskiyb 2017); E. mucophila is considered as a species with a narrow niche for $\mathrm{pH}$, and strongly associated to Sphagnum species (Hargan et al. 2015). Páramo lakes have large extensions of this moss (Schmidt-Mumm and Vargas-Ríos 2012), then this association could be used to evaluate possible habitat changes in these type of ecosystems.

\section{Diatom response to environmental gradients}

Diatom assemblages responded significantly to physical, chemical, and nutrient conditions. $\mathrm{pH}$ and alkalinity explained the greatest amounts of diatom variation. Water acidity has been identified as the main variable in explaining diatom variation in lake training sets (Chen et al. 2008; Hadley et al. 2013). In mountain lakes, the pH-alkalinity gradient is determined by geology, vegetation cover, chemical and biological processes, and some degree of acid deposition (Jacobsen and Dangles 2017). The lakes studied exhibit high heterogeneity of habitats, including peaty areas and extensive littorals zones colonized by macrophytes that favor 
the formation of humic acids, and therefore, low $\mathrm{pH}$ values (Jacobsen and Dangles 2017; Schmidt-Mumm and VargasRíos 2012). The statistical relationship between diatoms and these variables can enable the development of transfer functions to evaluate past processes of potential acidification in these lakes (Juggins and Birks 2012).

F. magaliesmontana, A. punctata, E. mucophila, and E. cf. incisatula were associated with low $\mathrm{pH}$. These pattern have been found in other ecosystems, in which, the acid condition is prevalent (Pan and Stevenson 1996; Siver and Baskette 2004; Rivera-Rondón and Catalan 2017). The highest abundance of these taxa found in acidic $\mathrm{pH}(<5)$, indicating their acidophilic nature (Round et al. 1990). In contrast, for high $\mathrm{pH}$ values the associated species were $S$. binodis, Sellaphora capitata, and Reimeria sinuata. This pattern has been found in arctic (Paull et al. 2008) and boreal environments, which has allowed these species to be categorized as alkalophilic (Jacques et al. 2016). S. pinnata, S. pseudoventralis, D. stelligera, and $H$. arcus had optima $\mathrm{pH}$ above 6.5; this assemblage is widely reported as an indicator of high pH environments (Bellinger and Sigee 2010). This shows that for each system there is a characteristic species group.

Although S. hemicyclus and Encyonopsis sp. No. 1 Ojo de Agua were associated with high percentages of radiation at the bottom $\left(\mathrm{I}_{\mathrm{z}}\right)$, no data are reported in the literature on this relationship. A few studies recorded the incidence of $\mathrm{I}_{\mathrm{z}}$ and its association with diatom assemblages (RiveraRondón and Catalan 2020). However, light irradiance is a fundamental driver of photosynthesis in the benthic flora (Hill 1996) whose deficiency very few species are adapted to (Burkholder 1996). For high elevation lakes, this variable is primarily a function of the depth, and controls the benthic/ planktonic diatom ratio in superficial sediments (Hofmann et al. 2020). This proportion allows study water column dynamics, for example water level, water transparency, and thermal stratification, factors related to productivity in these ecosystems (Plá-Rabés and Catalan 2018). Besides, lakes where light reaches the sediments can develop biofilms with autotrophic diatoms (Buchaca and Catalan 2007).

Our results indicated that diatoms could be used as an indicator of TP in these lakes, particularly Nitzschia, Navicula, and Pinnularia species. These genera have been reported as an indicator of high phosphorus concentrations in lakes of North of the Arctic Circle (Miettinen 2003), and in some cases, they have been related to eutrophic conditions (Lange-Bertalot 2001; Potapova et al. 2004). In systems of the French Alps, it was found that the species of the genus Pinnularia are abundant in high trophy environments (Feret et al. 2017). The relationship between diatom and the high TP values in the lakes studied can be explained because benthic algae are exposed to a higher phosphorous load due to sediment supply, which is stimulated in turn by hypoxia in this lacustrine compartment (Davidson and Jeppesen 2013).
Because most of the lakes are shallow and well lit at the bottom, there is a very productive algal biofilm that depends on phosphorus availability.

Based on total phosphorus two groups were differentiated: potentially mesotrophic indicator species, such as $P$. fibula, P. cf. microstauron and Eunotia spp., and eutrophic taxa, such as G. acuminatum, N. cf. lacuum, and N. cryptocephala. These are very similar associations to those found by Chen et al. (2008) in the Irish Ecoregion. Because these latter taxa exceeded the critical value of $0.3 \mathrm{mg} \mathrm{L}^{-1}$, they can be considered as indicators of contamination by increases in PT (Reavie and Smol 2001). Contrary to expectations, the centric diatoms showed no relationship with a high concentration of this nutrient, as documented in other systems around the world (Wang et al. 2009). This result can be related to the shallow depth of the lakes where planktonic algae are less favored.

$\mathrm{NO}_{3}{ }^{-}$was an explanatory variable of diatom distribution and related to $S$. robusta, but it needs a more detailed analysis to be used as an indicator of nitrogen eutrophication or deposition (Curtis et al. 2009). This element is considered as limiting of algae growth since it is one of the main constituents of biomolecules (Reynolds 2006). Despite there being a high numbers of species significantly related to this variable, the majority are in the high range of the variable. Also, as $\mathrm{NO}_{3}{ }^{-}$level depends on the oxygenation pattern, it favors the establishment of diatoms of the planktonic habit such as Aulacoseira, Tabellaria, and Discostella, among others (Sheibley et al. 2014). Remote mountain lakes are among the most sensitive ecosystems to deposition-induced eutrophication (Williams et al. 2017). In high elevation lacustrine ecosystems, the nitrogen deposition is mainly related to nitrate, which modifies the water chemical traits and induces shifts in diatom species composition (Kissman et al. 2013). In the context of shallow lakes, benthic diatoms are dominant, and considered less sensitive to nutrient input. However, there is evidence that benthic diatoms of high elevation lakes are responding to anthropogenic nitrogen, reflected in the correlation between $\delta^{15} \mathrm{~N}$ signatures and diatom composition (Spaulding et al. 2015). Besides, this shifts have been explained for the recent warming in the Andes, which has increased the abundance of planktonic diatom Discostella stelligera (Michelutti et al. 2015). S. venter, S. pinnata and $F$. constricta belonged to the group of diatoms in lakes of low $\mathrm{NO}_{3}{ }^{-}$concentration (mesotrophic condition). These species are characterized as highly adaptable due to their wide range of morphological variation (McGlynn et al. 2010) and broad tolerances to almost all environmental factors (Ponader and Potapova 2007). According to these ideas, these diatom taxa could be useful for studying increase of nitrogen deposition in páramo lakes.

Contrary to our hypothesis, TOC did not influence species distribution. Despite TOC is an essential variable in 
the growth of benthic algae (Rosén et al. 2009), its effect is not always direct on diatoms, mainly when evaluated on a gradient basis (Clarke 2003). This chemical characteristic is a result of interactions between other lake features related to water acidity and changes in light penetration, such as the different types of plant material in the basin, and altitude, depth, and area of the lake (Hansson 1992; Kullberg et al. 1993). Possibly, TOC does not act as a limiting element but as a condition in these lakes. Thus, due to the high TOC values, the species present can be expected to be very well adapted to these conditions, so they do not show segregation along the environmental gradient.

In conclusion, the diatoms of the studied lakes showed a significant ecological relationship with environmental variables. The analysis of diatom distribution and abundance in the surface sediments provided independent quantitative information to indicate changes in $\mathrm{pH}$, alkalinity, nutrients, and light environment. There was not a significant effect of TOC on species distribution. Diatom species showed a significant relationship with TP and $\mathrm{NO}_{3}{ }^{-}$and the irradiance at the bottom, variables having significant relevance for studying the recent impact of global change factors on the tropical mountain lakes.

Supplementary Information The online version contains supplementary material available at https://doi.org/10.1007/s00027-021-00838-z.

Acknowledgements This study was funded by Ministerio de Ciencia, Tecnología e Innovación of Colombia (Colciencias 50000-050-2016) and Pontificia Universidad Javeriana (IDPPTA 6789). C. Muñoz-López was supported by a PhD scholarship Colciencias-Colfuturo (No. 779 2017-Regiones Boyacá). Thanks to Parques Nacionales Naturales de Colombia (Resolución No. 141-241016) and to the staff of the PNN Chingaza, PNN Sumapaz, SFF Guanentá Alto Río Fonce, SFF lguaque, and PNN Pisba, for their invaluable help during the field work. Thanks to the project field work team: D. Valoyes, Y. Caleño, D. Castillo, M. Guerrero, and L. Garzón for their invaluable help in exploring the mountains lakes.

Author contributions CR-R authors contributed to the study conception and design. Both authors contributed to material preparation, data collection, analysis and manuscript revision. Both authors read and approved the final manuscript.

Funding This study was funded by Ministerio de Ciencia, Tecnología e Innovación of Colombia MinCiencias (50000-050-2016) and Pontificia Universidad Javeriana (IDPPTA 6789). C. Muñoz-López was supported by a PhD scholarship MinCiencias-Colfuturo (No. 779 2017-Regiones Boyacá).

\section{Declarations}

Conflict of interest The authors declare that they have no conflict of interest.

Ethical approval The project was approved by the Research Ethics Committee of Science School of the Pontificia Universidad Javeriana (Session June 14, 2015).
Consent for publication Authors authorize the publication of this manuscript.

Open Access This article is licensed under a Creative Commons Attribution 4.0 International License, which permits use, sharing, adaptation, distribution and reproduction in any medium or format, as long as you give appropriate credit to the original author(s) and the source, provide a link to the Creative Commons licence, and indicate if changes were made. The images or other third party material in this article are included in the article's Creative Commons licence, unless indicated otherwise in a credit line to the material. If material is not included in the article's Creative Commons licence and your intended use is not permitted by statutory regulation or exceeds the permitted use, you will need to obtain permission directly from the copyright holder. To view a copy of this licence, visit http://creativecommons.org/licenses/by/4.0/.

\section{References}

Alvial IE, Cruces FJ, Araneda AE, Urrutia RE, Grosjean M (2008) Diatoms community structure in superficial sediments of eight Andean lakes of central Chile. Rev Chil Hist Nat 81:83-94

APHA, AWWA, WEF (2012) Standard methods for examination of water and wastewater 22nd ed, Washington, DC

Battarbee RW (1986) Diatom analysis. In: Berglund E (ed) Handbook of holocene palaeoecology and palaeohydrology. John Wiley \& Sons, Chichester, pp 527-570

Beier T, Lange-Bertalot H (2007) A synopsis of cosmopolitan, rare and new Frustulia species (Bacillariophyceae) from ombrotrophic peat bogs and minerotrophic swamps in New Zealand. Nova Hedwigia 85:73-91

Bellinger E, Sigee D (2010) Freshwater algae: identification and use as bioindicators. John Wiley \& Sons Ltd, USA

Benito X, Fritz SC, Steinitz-Kannan M, Vélez MI, McGlue MM (2018a) Lake regionalization and diatom metacommunity structuring in tropical South America. Ecol Evol 8:7865-7878

Benito X, Fritz SC, Tapia PM, Steinitz-Kannan M, Kelly MA, Lowell TV (2018b) Geo-climatic factors drive diatom community distribution in tropical South American freshwaters. J Ecol 106:1660-1672

Benito X, Vilmi A, Luethje M, Carrevedo MA, Lindholm M, Fritz SC (2020) Spatial and temporal ecological uniqueness of Andean diatom communities are correlated with climate, geodiversity and long-term limnological change. Front Ecol Evol 8:260. https://doi.org/10.3389/fevo.2020.00260

Bouchard G, Gajewski K, Hamilton PB (2004) Freshwater diatom biogeography in the Canadian arctic archipelago. J Biogeogr 31:1955-1973

Buchaca T, Catalan J (2007) Factors influencing the variability of pigments in the surface sediments of mountain lakes. Freshw Biol 52:1365-1379

Burkholder JM (1996) Interactions of benthic algae with their substrata. In: Stevenson J, Bothwell M, Lowe L (eds) Algal ecology: freshwater benthic ecosystems. Academic Press, San Diego, pp 253-297

Buytaert W, Célleri R, De Bièvre B, Cisneros F, Wyseure G, Deckers J, Hofstede R (2006) Human impact on the hydrology of the Andean páramos. Earth Sci Rev 79:53-72

Canani LGC, Fraia RS, Melo, S (2018) Periphytic Actinella Lewis (Ochrophyta, Bacillariophyceae) species from an environmental protection area in the Brazilian Amazon. Acta Limnologica Brasiliensia e209 
Castro C, Agualimpia Y, Sánchez F (2016) Modelo climático de los páramos de la cordillera Oriental colombiana aplicado a regímenes de temperatura del suelo. Perspectiva Geográfica $21: 33-62$

Catalan J, Donato Rondón JC (2016) Perspectives for an integrated understanding of tropical and temperate high-mountain lakes. J Limnol 75:215-234

Catalan J, Pla-Rabés S, Camarero L, Wolfe AP, Smol JP, Rühland KM, Anderson NJ, Kopáček J, Stuchlík E, Schmidt R, Koinig KA, Psenner R, Flower RJ, Heiri O, Kamenik C, Korhola A, Leavitt PR, Renberg I (2013) Global change revealed by palaeolimnological records from remote lakes: a review. J Paleolimnol 1:1-23

Clarke G (2003) The relationship between diatoms and climate in a European mountain lake training set: Implications for detecting the Little Ice Age in lake sediments from Central Norway. University College of London, p 433

Costa LF, Wetzel CE, Lange-Bertalot H, Ector L, Bicudo DC (2017) Taxonomy and ecology of Eunotia species (Bacillariophyta) in southeastern Brazilian reservoirs, p 302

Curtis CJ, Juggins S, Clarke G, Battarbee RW, Kernan M, Catalan J, Thompson R, Posch M (2009) Regional influence of acid deposition and climate change in European mountain lakes assessed using diatom transfer functions. Freshw Biol 54:2555-2572

Chen G, Dalton C, Leira M, Taylor D (2008) Diatom-based total phosphorus (TP) and $\mathrm{pH}$ transfer functions for the Irish Ecoregion. $\mathrm{J}$ Paleolimnol 40:143-163

Davidson TA, Jeppesen E (2013) The role of palaeolimnology in assessing eutrophication and its impact on lakes. J Paleolimnol 49:391-410

DeNicola DM, De Eyto E, Wemaere A, Irvine K (2004) Using epilithic algal communities to assess trophic status in Irish lakes. J Phycol 40:481-495

Díaz-Quirós C, Rivera-Rondón CA (2004) Diatomeas de pequeños ríos andinos y su utilización como indicadoras de condiciones ambientales. Caldasia 26(2):381-394

Donato Rondón JC (2001) Fitoplancton de los lagos andinos del norte de Sudamérica (Colombia) composición y factores de distribución. Academia Colombiana de Ciencias Exactas, Físicas y Naturales, Bogotá

Feret L, Bouchez A, Rimet F (2017) Benthic diatom communities in high altitude lakes: a large scale study in the French Alps. Ann Limnol 53:411-423

García-Berthou E, Alcaraz L, Benejam L, Benito J. (2009) Diseño experimental y análisis de datos. In: Sabater AES (ed), Conceptos y técnicas en ecología fluvial Editorial Fundación BBVA, Bilbao, pp 397-412

Glushchenkoa AM, Kulikovskiyb MS (2017) Taxonomy and distribution of the Genus Eunotia Ehrenberg in aquatic ecosystems of Vietnam. Inland Water Biology 10(2):130-139

Gómez E, Jordan T, Allmendinge RW, Hegarty K, Kelley S (2005) Syntectonic Cenozoic sedimentation in the northern middle Magdalena Valley Basin of Colombia and implications for exhumation of the Northern Andes. Geol Soc Am Bull 117(5/6):547-569

Gunkel G (2003) Limnology of a High Mountain Tropical Lake, in Ecuador: characteristics of sediments and rate of sedimentation (Spanish). Rev Biol Trop 51:381-390

Hadley KR, Douglas MSV, Lim D, Smol JP (2013) Diatom assemblages and limnological variables from 40 lakes and ponds on Bathurst Island and neighboring high Arctic islands. Int Rev Hydrobiol 98:44-59

Hargan KE, Rühland KM, Paterson AM, Finkelstein SA, Holmquist JR, MacDonald GM, Keller W, Smol JP (2015) The influence of water-table depth and $\mathrm{pH}$ on the spatial distribution of diatom species in peatlands of the Boreal Shield and Hudson Plains, Canada. Botany 93:57-74
Hansson L-A (1992) Factors regulating periphytic algal biomass. Limnol Oceanogr 37:322-328

Hill W (1996) Effects of light. In: Stevenson J, Bothwell M, Lowe L (eds) Algal ecology: freshwater benthic ecosystems. Academic Press, San Diego, pp 121-148

Hofmann G, Werum M, Lange-Bertalot H (2011) Diatomeen im Süßwasser - Benthos von Mitteleuropa. Bestimmungsflora Kieselalgen für die ökologische Praxis. Über 700 der häufigsten Arten und ihre Ökologie. A.R.G. Gantner Verlag K.G., Ruggell

Hofmann A, Geist J, Nowotny L, Raeder U (2020) Depth-distribution of lake benthic diatom assemblages in relation to light availability and substrate: implications for paleolimnological studies. J Paleolimnol 64:315-334

Jacobsen D, Dangles O (2017) Ecology of high altitude waters. Oxford University Press, United Kingdom

Jacques O, Bouchard F, Pienitz R, MacDonald LA, Hall RI, Wolfe BB (2016) Distribution and diversity of diatom assemblages in surficial sediments of shallow lakes in Wapusk National Park (Manitoba, Canada) region of the Hudson Bay Lowlands. Ecol Evol 6:4526-4540

Juggins S (2020) Rioja: analysis of quaternary science data. RPackage. Version (0.9-26)

Juggins S, Birks HJB (2012) Quantitative environmental reconstructions from biological data. In: Birks HJB, Lotter AF, Juggins S, Smol JP (eds) Tracking environmental change using lake sediments. Springer, Netherlands, pp 431-494

Krammer K (1997) Die cymbelloiden Diatomeen. Eine Monographie der weltweit bekannten Taxa. Teil 2. Encyonema part Encyonopsis and Cymbellopsis. Bibl Diatomol 37:1-469

Kilroy C, Biggs BJF, Vyverman W (2007) Rules for macroorganisms applied to microorganisms: patterns of endemism in benthic freshwater diatoms. Oikos 116:550-564

Kilroy C, Biggs BJF, Vyverman W, Broady PA (2006) Benthic diatom communities in subalpine pools in New Zealand: relationships to environmental variables. Hydrobiologia 561:95-110

Kissman CEH, Williamson CE, Rose KC, Saros JE (2013) Response of phytoplankton in an alpine lake to inputs of dissolved organic matter through nutrient enrichment and trophic forcing. Limnol Oceanogr 58:867-880

Köster D, Raca JJM, Pienitz R (2004) Diatom-based inference models and reconstructions revisited: methods and transformations. J Paleolimnol 32:233-246

Kullberg A, Bishop KH, Hargeby A, Jansson M, Petersen RC (1993) The ecological significance of dissolved organic carbon in acidified waters. Ambio 22:331-337

Lange BH (2001) Navicula sensu stricto, 10 genera separated from Navicula sensu lato, Frustulia. In: Lange Bertalot H (ed) Diatoms of Europe diatoms of the European inland waters and comparable habitats. Rugell, Gantner, p 526

Lange BH, Bak M, Witkowski A (2011) Eunotia and some related genera. In: Lange Bertalot $\mathrm{H}$ (ed) Diatoms of Europe - diatoms of the European inland waters and comparable habitats. Ruggell, Gantner, p 747

Legendre P, Gallagher ED (2001) Ecologically meaningful transformations for ordination of species data. Oecologia 129:271-280

Lepš J, Šmilauer P (2003) Multivariate analysis of ecological data using CANOCO. Cambridge University Press, Cambridge, UK

Linares Cuesta JE, Olofsson L, Sánchez-Castillo P (2007) Comunidades de diatomeas epipélicas en las lagunas de alta montaña de Sierra Nevada (Granada, España). Limnetica 26:99-113

Margalef R (1983) Limnología. Ediciones Omega, S. A, Barcelona

McCune B, Grace J (2002) Analysis of ecological communities. OR: $\mathrm{MjM}$ software design, Gleneden Beach

McGlynn G, Mackay AW, Rose NL, Taylor RG, Leng MJ, Engstrom DG (2010) Palaeolimnological evidence of environmental 
change over the last 400 years in the Rwenzori Mountains of Uganda. Hydrobiologia 648:109-122

Melo S, Torgan LC, Raupp SV (2010) Actinella species (Bacillariophyta) from an Amazon blackwater floodplain lake (AmazonasBrazil). Acta Amazon 40:269-274

Metzeltin D, Lange-Bertalot H (1998) Tropical diatoms of South America I: about 700 predominantly rarely known or new taxa representative of the Neotropical flora. Koeltz Scientific Book, Königstein, p 695

Metzeltin D, Lange-Bertalot H (2007) Tropical diatoms of South America II: special remarks on biogeographic disjunction. Koeltz Scientific Books, Königstein, p 877

Michelutti N, Wolfe AP, Cooke CA, Hobbs WO, Vuille M, Smol JP (2015) Climate change forces new ecological states in Tropical Andean Lakes. PLoS One 10(2):e0115338

Miettinen J (2003) A diatom-total phosphorus transfer function for freshwater lakes in southeastern Finland, including cross-validation with independent test lakes. Boreal Environ Res 8:215-228

Mirande V, Tracanna BC (2009) Estructura y controles abióticos del fitoplancton en humedales de altura. Ecol Austral 19:119-128

Narváez-Bravo G, León-Aristizábal G (2001) Caracterización y Zonificación Climática De La Región Andina Meteorología Colombiana 4:121-126

Nagy S (2011) Collecting, cleaning, mounting and photographing diatoms. In: Seckbach J, Kociolek P (eds) The diatom world. Springer Science + Business Media, New York, pp 3-18

Oksanen J, Kindt R, Legendre P, O'Hara B, Simpson GL, Solymos P, Stevens MHH and Wagner H (2020) Vegan: community ecology package. R package version 2.5-7. Vegan: Community Ecology Package

Oksanen J, Läärä E, Huttunen P, Meriläinen J (1988) Estimation of $\mathrm{pH}$ optima and tolerances of diatoms in lake sediments by the methods of weighted averaging, least squares and maximum likelihood, and their use for the prediction of lake acidity. J Paleolimnol 1:39-49

Pan Y, Stevenson RJ (1996) Gradient analysis of diatom assemblages in Western Kentucky wetlands. J Phycol 32:222-232

Paull TM, Gajewski K, Hamilton PB, LeBlanc M (2008) Numerical analysis of small Arctic diatoms (Bacillariophyceae) representing the Staurosira and Staurosirella species complexes. Phycologia 47:213-224

Pedraza- Garzón E, Donato-Rondón J (2011) Diversidad y distribución de diatomeas en un arroyo de montaña de los andes colombianos. Caldasia 33(1):177-191

Plá-Rabés S, Catalan J (2018) Diatom species variation between lake habitats: implications for interpretation of paleolimnological records. J Paleolimnoly 60:169-187

Ponader KC, Potapova MG (2007) Diatoms from the genus Achnanthidium in flowing waters of the Appalachian Mountains (North America): ecology, distribution and taxonomic notes. Limnologica 37:227-241

Potapova MG, Charles DF, Ponader KC, Winter DM (2004) Quantifying species indicator values for trophic diatom indices: a comparison of approaches. Hydrobiologia 517:25-41

Reavie E, Smol JP (2001) Diatom-environmental relationships in 64 alkaline southeastern Ontario (Canada) lakes: a diatom-based model for water quality reconstructions. J Paleolimnol 25:25-42

Reavie E, Axler RP, Sgro GV, Danz NP, Kingston J, Kireta A, Brown TN, Hollenhorst T, Ferguson M (2006) Diatom-based weightedaveraging transfer functions for great lakes coastal water quality: relationships to watershed characteristics. J Great Lakes Res 32(2):321-347

Reynolds C (2006) The ecology of phytoplankton. Cambridge University Press, New York

Rivera Rondón CA, Catalan J (2017) Diatom diversity in the lakes of the Pyrenees: an iconographic reference. Limnetica 36:127-395
Rivera-Rondón CA, Catalan J (2020) Diatoms as indicators of the multivariate environment of mountain lakes. Sci Total Environ 703:135517

Rosén P, Cunningham L, Vonk J, Karlsson J (2009) Effects of climate on organic carbon and the ratio of planktonic to benthic primary producers in a subarctic lake during the past 45 years. Limnol Oceanogr 54:1723-1732

Rosén P, Hall R, Korsman T, Renberg I (2000) Diatom transfer-functions for quantifying past air temperature, $\mathrm{pH}$ and total organic carbon concentration from lakes in northern Sweden. J Paleolimnol 24:109-123

Round FE, Crawford RM, Mann DG (1990) The diatoms: biology and morphology of the genera. Cambridge Press, United Kingdom

Ruiz E (2002) Métodos para el estudio de las características Físicoquímicas del agua. In: Rueda-Delgado G (ed) Manual de Métodos en Limnología. Bogotá, Asociación Colombiana de Limnología, pp 9-27

Rumrich U, Lange Bertalot H, Rumrich M (2000) Diatomeen der Anden: Von Venezuela bis Patagonien/Tierra del Fuego. Koeltz Scientific Books, Königstein, p 649

Sala S, Duque SR, Núñez-Avellaneda M, Lamaro A (2002) Diatoms from the Colombian Amazon: some species of the genus Eunotia (Bacillariophyceae). Acta Amazónica 32:589-603

Schmidt-Mumm U, Vargas-Ríos O (2012) Comunidades vegetales de las transiciones terrestre-acuáticas del páramo de Chingaza, Colombia. Rev Biol Trop 60:36-64

Schmidt R, Kamenik C, Lange-Bertalot H, Klee R (2004) Fragilaria and Staurosira (Bacillariophyceae) from sediment surfaces of 40 lakes in the Austrian Alps in relation to environmental variables, and their potential for palaeoclimatology. J Limnol 63:171-189

Sheibley RW, Enache M, Swarzenski PW, Moran PW, Foreman JR (2014) Nitrogen deposition effects on diatom communities in lakes from three national parks in Washington State. Water Air Soil Pollution 225:1857-1880

Sierra-Arango O, Alves de Souza P, Velásquez C (2014) Taphonomic signatures and paleoecology of holocene diatom assemblages in the Llano Grande basin, northwestern Andean cordillera. Colombia Rev Bras Paleontol 17(2):123-140

Sioli H (1984) The Amazon and its main affuents: hydrography, morphology of the river course, and river types. In: Sioli H (ed) The Amazon; Limnology and landscape ecology of a mighty tropical river and its basin. Dr. W. Junk Publishers, Boston, pp 127-165

Siver PA, Baskette G (2004) A morphological examination of Frustulia (Bacillariophyceae) from the Ocala National Forest, Florida, USA. Can J Bot 82:629-644

Siver PA, Bishop J, Lott A, Wolfe AP (2015) Heteropolar eunotioid diatoms (Bacillariophyceae) were common in the North American Arctic during the middle Eocene. J Micropalaeontol 34:151-163

Smol JP (2008) Pollution of lakes and rivers: a paleoenvironmental perspective, 2nd edn. Blackwell Publishing, Oxford

Smol JP, Cumming BF, Dixit AS, Dixit SS (1998) Tracking recovery patterns in acidified lakes: A paleolimnological perspective. Restor Ecol 6:318-326

Spaulding SA, Bishop IW, Edlund MB, Lee S, Furey P, Jovanovska E, Potapova M (2021) Diatoms of North America. Retrieved from https://diatoms.org/

Spaulding SA, Otu MK, Wolfe AP, Baron JS (2015) Paleolimnological records of nitrogen deposition in shallow, high-elevation lakes of Grand Teton National Park, Wyoming, U.S.A. Arctic, Antarctic, an Alpine Research 47(4):703-717

Ter Braak CJF (1986) Canonical correspondence analysis: a new eigenvector technique for multivariate direct gradient analysis. Ecology 67:1167-1179

Ter Braak CJF, Verdonschot PFM (1995) Canonical correspondence analysis and related multivariate methods in aquatic ecology. Aquat Sci 57:255-289 
Thomas E, John J (2010) Diatoms in wetlands from the south-west of Western Australia: community structure in relation to $\mathrm{pH}$. J R Soc West Aust 93:29-42

Tolotti M (2001) Phytoplankton and littoral epilithic diatoms in high mountain lakes of the Adamello-Brenta Regional Park (Trentino, Italy) and their relation to trophic status and acidification risk. J Limnol 60:171-188

Wang Q, Zhi C, Hamilton P, Kang F (2009) Diatom distributions and species optima for phosphorus and current velocity in rivers from ZhuJiang Watershed within a Karst region of south-central China. Fundamental Appl Limnol Archiv Für Hydrobiologie 175:125-141

Wetzel CE (2011) Biodiversidade e distribuição espacial de diatomáceas (Bacillariophyceae) na bacia hidrográfica do Rio Negro, Amazonas, Brasil., Instituto de Botânica, São Paulo, p 1912
Wetzel R, Likens G (2000) Limnological analyses, 2nd edn. Springer Science + Business Media, New York

Williams JJ, Lynch JA, Saros JE, Labou SG (2017) Critical loads of atmospheric $\mathrm{N}$ deposition for phytoplankton nutrient limitation shifts in western US mountain lakes. Ecosphere 8(10):e01955

Zapata A, Rivera-Rondón CA, Valoyes D, Muñoz-López CL, MejíaRocha M, Catalan J (2021) Páramo Lakes of Colombia: an overview of their geographical distribution and physicochemical characteristics. Water 13:2175

Publisher's Note Springer Nature remains neutral with regard to jurisdictional claims in published maps and institutional affiliations. 